\title{
Kağıt ve Kağıt Ürünleri Üretimi ve Gayri Safi Yurt içi Hasılanın Elektrik Enerjisi Tüketimine Etkisi
}

\author{
Özlem AKAY*1@ \\ ${ }^{1}$ Çukurova Üniversitesi, Fen Edebiyat Fakültesi, İstatistik Bölümü, 01380, Adana
}

(Alınış / Received: 15.05.2019, Kabul / Accepted: 02.10.2019, Online Yayınlanma/ Published Online: 30.12.2019)

\section{Anahtar Kelimeler}

Elektrik tüketimi, Gayri safi yurt içi hasıla, Kağıt ve kağıt ürünleri, Panel veri

\begin{abstract}
Özet: Enerji, ekonomik ve endüstriyel kalkınma için önemli ve üretim sürecinin devamı için vazgeçilmez bir üretim girdisidir. Kolay kullanım ve diğer avantajları sebebiyle ekonomik ve sosyal yaşamın oldukça geniş bir bölümünde yaygın olarak elektrik enerjisinden yararlanılmaktadır. Bu çalışmanın amacı, kağıt ve kağıt ürünleri üretimi ve ekonomik büyümenin bir göstergesi olan gayri safi milli hasılanın elektrik enerjisi tüketimi üzerindeki etkisini panel veri analizi ile incelemektir. Bu amaç doğrultusunda, Eurostat ve Wordbank'tan elde edilen 20062016 yılları arasında 20 OECD ülkesi için panel veri seti oluşturulmuştur. Model için yatay kesit bağımlılığı, değişen varyans ve otokorelasyon varsayımları sınanmış ve varsayımlardan sapma olduğu görülmüştür. Bu sapmalara dirençli Driscoll-Kraay tahmin edici kullanılarak parametreler tahmin edilmiștir. Analiz sonucunda, kağıt ve kağıt ürünleri üretiminde meydana gelecek \%1'lik bir artış elektrik enerjisi tüketimini \%0.22 oranında, kişi başı gayri safi milli hasıladaki \%1'lik bir artışın ise elektrik tüketiminde yaklaşık olarak $\% 0.62$ dolayında arttırdığı bulgusuna ulaşılmıştır.
\end{abstract}

\section{The Effect of Production of Paper and Paper Products and Gross National Product on Electricity Consumption}

\section{Keywords}

Consumption of electricity, Gross domestic product, Paper and paper products, Panel data

\begin{abstract}
Energy is an important in put for economic and industrial development and an indispensable production input for the continuation of the production process. In a very large part of economic and social life, electrical energy is widely used because of its easy usage and other advantages. The aim of this study is to investigate the effect of the production of paper and paper products and the gross national product, which is an indicator of economic growth, on the consumption of electricity by panel data analysis. For this purpose, a panel data set was established for 20 OECD countries between 2006 and 2016 from Eurostat and Wordbank. Crosssectional dependence, heteroskedasticity and autocorrelation assumptions were tested for the model and deviations from the assumptions were observed. Parameters were estimated using the Driscoll-Kraay estimators, which are resistant to these deviations. As a result of the analysis, it was found that an increase of $1 \%$ in the production of paper and paper products increased the electrical energy consumption by $0.22 \%$, the increase of $1 \%$ in the per capita gross domestic product increased approximately $0.62 \%$ in electricity consumption.
\end{abstract}

\section{Giriş}

Enerjiye duyulan ihtiyaç, insanların yaşam koşullarındaki değişimlere bağlı olarak hem kullanım hem de çeşitlik açısından farklılıklar göstermiştir [1]. Önemli bir üretim girdisi olan enerji, küreselleşmeyle birlikte ekonomik büyüme için de önemli bir girdi haline gelmiştir. Böylece, ülkelerin enerjiye olan ihtiyaçları bağımlılıkları daha da artmıştır.
Enerji, ekonomik büyümeyi etkileyen tek faktör değildir ancak önemli bir girdidir. Bir bölgedeki ekonomik büyüme ve enerji talebi arasındaki ilişki, o bölgedeki ekonomik kalkınma seviyesi ve bireylerin yaşam standartlarından önemli ölçüde etkilenmektedir [2]. Ekonomik büyümeyle ilişkili olarak yeni ve farklı kullanım alanlarının ortaya çıkması elektrik enerjisi tüketimi arttırmakta iken, ekonomide ortaya çıkan kriz ve diğer olumsuz 
durumlar ise elektrik tüketimini azaltmaktadır [3]. Gelișmiș ülkelerin seviyelerini koruyabilmesi ve gelişmekte olan ülkelerinde gelişmiş ülkelerin seviyelerine erişebilmesi sanayileşme ile mümkün olacaktır. Sürekli ve sıhhatli bir şekilde sanayileşme ise ucuz ve güvenilir enerji üretim politikalarının başarılı bir şekilde uygulanmasına bağlıdır [4].

En kaliteli enerji bileşeni olduğu iddia edilen elektriğin enerji tüketimi içerisindeki payı hızla artmaktadır. Bu eğilimin başlıca sebepleri; elektriğin hızla iletilebilen, güvenilir, kullanım alanı oldukça geniş, ihtiyaç duyulduğu anda üretilip eş zamanlı olarak tüketilebilen, kaliteli, verimli ve çevreye zararsız bir enerji kaynağı olmasıdır [5]. Ekonominin diğer sektörlerine büyük miktarda girdi sağlayan elektrik enerjisi sektörü, diğer sektörlerdeki gelişmelerden etkilendiği gibi diğer sektörlerin gelişimini de etkilemektedir.

Ekonomik kalkınmaya paralel olarak çeșitli mal ve hizmet tüketimi artmaktadır. Refah seviyesinin yükseldiği ülkelerde kâğıt tüketiminde artış olduğu görülmektedir. Kâğıt üretimini sadece toplumsal refah artışından etkilenen bir sanayi ürünü değilken kâğıt üretiminin refah seviyesini etkileme özelliği bulunmaktadır. Kâğıt üretim çıktıları farklı iktisadi sektörlerin girdisi olarak ekonomik etkiler yaratmanın yanı sıra, eğitim-öğretim ve sağlık alanlarında da sosyal sonuçlara neden olmaktadır. Sosyal yaşamın bir parçası olan eğitim ihtiyacının artması ve yükselen sağlı standartları daha fazla kâğıt kullanmayı-üretmeyi gerektirmektedir. İktisadi gelişme ile işlem hacmini artırmaktadır. Böylece iç ve dış piyasalar için elde edilen üretimlerin gerektirdiği ambalaj malzemesi ihtiyacı yükseltmektedir. Bu gelişime, en yaygın ambalaj malzemelerinden biri olan kâğıdın talebini ve üretimini arttırmakta ve kâğıt sanayi büyümektedir. Bununla birlikte, elektronik alanda yaşanan gelişimin kâğıdın bazı kullanım alanlarını daraltabileceği yönünde görüşler olsa da, insanlığın kâğıt kullanımına devam edeceği fakat ürünün kullanım alanlarında farklılıklar olabileceği düșünülmektedir. Kâğıt, kullanım alanının yaygınlığ ile sosyal ve ekonomik etkileri yüksek ürünler arasındadir [6].

Lifler ve çeşitli kimyasal maddelerden oluşan kağıt, sanayi ve kültür alanındaki yeri ile insanlığın en önemli ihtiyaç maddelerinden biridir. Kağıt ve kağıt hamuru üretiminde lifler ve kimyasal maddeler dışında büyük miktarda su, buhar ve elektrik enerjisi kullanılmaktadır. Sektörde, toplam maliyetlerin \%2025 'ini enerji gideri oluşturmaktadır. Bu nedenle, kağıt ve kağıt hamuru üretiminde çevre ile ilgili en önemli hususlardan biri enerji tüketimi olmaktadır. Ayrıca sektör için enerji fiyatlarının yüksekliği de önemli bir sorun teşkil etmektedir.

2013 yılında dünya genelinde 274 milyon ton civarında kağıt ve kağıt ürünleri üretimi gerçekleşmiştir. Ambalaj ve etiket kağıdı sektördeki toplam üretimin yaklaşık yarısını oluşturmaktadır. 76 milyon tonluk üretim hacmi ile yazı ve baskı kağıdı sektörün en büyük ikinci ürünü olmuştur. Toplam üretimin yaklaşık \%9'unu gazete ve temizlik kağıdı kalemleri oluştururken, toplam üretimin \%5'i diğer kağıt ve karton ürünleridir. Önümüzdeki yıllarda sektör genelinde üretimin büyümeye devam edeceği tahmin edilmektedir. Ürün bazında değerlendirildiğinde, teknolojik gelişmelerle birlikte dijitalleşmenin hızlandığı günümüz dünyasında gazete ile yazı ve baskı kağıdı üretimlerinin sektördeki payının azalması, temizlik kağıdı ile ambalaj ve etiket kağıdı ürünlerinin ise artması beklenmektedir. Kağıt ve kağıt ürünleri sektöründe hammaddeye erişim kolaylığı ve sermaye birikimi gibi faktörler ülkelerin büyüme potansiyelinde belirleyici olmaktadır [7].

Bir ülkenin sanayi ve kültürel gelişmişlik düzeylerinin belirleyici etmenlerinden biri de kağıt sanayinin gelişmesi olarak kabul edilmektedir.

Enerji ekonomisi alanında yapılan çalışmaların sayısındaki artış, bu alanda geniş bir literatür oluşturmuştur. Ampirik literatür araştırması kapsamında değerlendirilen çalışmalar incelendiğinde, enerji tüketimi ile ekonomik büyüme arasındaki ilişkinin farklı değişkenler ve modeller çerçevesinde ele alındığı tespit edilmiştir. Bu bağlamda ekonomik büyümeyi temsilen genellikle reel Gayri Safi Yurt İçi Hasıla (GSYH) veya kişi başına GSYH değişkeni kullanılırken enerji tüketimini temsilen toplam enerji kullanımı, yenilenebilir enerji tüketimi, elektrik tüketimi veya kişi başına elektrik tüketiminin kullanıldığı görülmektedir. Farklı değişkenleri modele dahil eden diğer bazı çalışmalarda ise, ekonomik büyümenin diğer belirleyicileri olan işgücü kullanımı (istihdam) ve sermaye birikimi gibi değişkenler kullanılmıştır. Literatürde tek ülke için yapılan araştırmalar bulunduğu gibi birden fazla ülke veya ülke grupları da içinde araştırmalar yapılmıştır.

Ghaderi vd. [8] çalıșmalarında, İran sanayisinde ekonomik büyüme ile elektrik tüketimi arasındaki ilişkiyi incelemişlerdir. Nedensellik testi sonuçlarına göre, elektrik tüketimi İran'daki çoğu endüstriye herhangi bir katkı sağlamamıștır. Bu nedenle elektrik tüketimini artırmadaki destekleyici politikalar ekonomik büyümede yetersiz olduğu görülmüştür.

Saatçi ve Dumrul [9] çalışmalarında, Türkiye için elektrik tüketimi ve ekonomik büyüme arasındaki ilişkiyi 1960-2008 dönemi verilerini kullanarak Düzeltilmiş En Küçük Kareler Yöntemi (FMOLS) ve Dinamik En Küçük Kareler Yöntemi (DOLS) kullanarak incelemişlerdir. Her iki yöntem ile elde sonuçlar, Türkiye'de elektrik tüketiminin ekonomik büyümeyi pozitif olarak etkilediğini, elektrik tüketimindeki \%1'lik artışın ise ekonomik büyümeyi uzun dönemde \%0.33-\%0.37 oranında artırdığını göstermiştir. 
Altıntaş ve Mercan [10] çalışmalarında, OECD üyesi G-ll ülkelerinin 1980-2011 dönemine ait elektrik tüketimi ile ekonomik büyüme arasındaki ilişkiyi incelemișlerdir. Ayrıca sermaye birikimi ve işgücü değişkenlerini de kullanılarak panel eşbütünleşme yardımıyla test etmişlerdir. Panel Granger nedensellik testi ile uzun dönemde elektrik tüketimi ve ekonomik büyüme arasında çift yönlü nedenselliğin olduğunu belirlemişlerdir. Elde edilen sonuçlara göre, teorik beklentilere uyumlu olarak elektrik tüketimi, sermaye birikimi ve işgücü değişkenlerinin ekonomik büyümeyi pozitif yönde etkilediği sonucuna ulaşmışlardır.

Ergün ve Polat [11] çalışmalarında, 1980-2010 yılları arasında OECD ülkelerinde CO2 emisyonu, elektrik tüketimi ve ekonomik büyüme arasında ilişki olup olmadığını analiz etmişlerdir. Panel eşbütünleşme testleri sonucunda 30 OECD ülkesinde CO2 emisyonu, Gayri Safi Yurtiçi Hasıla (GSYH) ve elektrik tüketimi arasında eşbütünleşme ilişkisi olduğu sonucuna varılmıştır. Uzun dönem tahminciler 30 OECD ülkesinin çoğunluğunda elektrik tüketimi ve $\mathrm{CO} 2$ emisyonu arasında istatistiki olarak anlamlı bir ilişkinin olduğunu göstermiştir. Ayrıca, CO2 emisyonu ve ekonomik büyüme arasında doğrusal olmayan bir ilişkinin varlığını ifade eden Çevresel Kuznets Eğrisi (ÇKE) hipotezini destekleyen sonuçlara ulaşılmıştır. Son olarak Panel Vektör Hata Düzeltme Modeli (VECM) sonuçları 30 OECD ülkesinde kısa dönemde GSYH ile CO2 emisyonu arasında tek yönlü nedensellik ilişkisi olduğunu ve GSYH ile elektrik tüketimi arasında çift yönlü nedensellik ilişkisi olduğunu göstermektedir.

İsmiç [4] çalışmasında, IMF ülke listesinin gelişmekte olan ülkeler grubundaki 8 ülkenin 1990-2012 yılları arasında, elektrik tüketimi, ekonomik büyüme ve nüfus verilerini ele alarak, değişkenler arasındaki ilişkinin yönü ve büyüklüğünü incelemiştir. Görünüşte İlişkisiz Regresyon ve Swamy'nin Tesadüfi Katsaylar modellerini kullanarak, ekonomik büyümenin elektrik tüketimini pozitif yönde etkilediği, 2 ülkede ise nüfusun elektrik tüketimini etkilemediği sonucuna ulaşmıştır.

Karanfil ve Li [12] çalıșmalarında, elektrik bağımlılı̆̆ derecesini ve şehirleşme düzeyini hesaba katarak 1980-2010 dönemi için 160 ülkenin kişi başına elektrik tüketimi ve kiși bașına GSYIH'nın panel verilerini kullanarak, elektrik tüketimi ve ekonomik faaliyetler arasındaki uzun ve kısa dönem dinamiklerini incelemişlerdir.

Eren vd. [13] çalışmalarında, Türkiye'de 1975-2013 dönemine ilişkin elektrik tüketimi ile ekonomik büyüme arasındaki ilişkiyi incelemişlerdir. Yapılan analiz sonuçlarına göre, değişkenler arasında uzun dönem etkileşimi tespit edilmiş, uzun dönem analizinde Türkiye'nin elektrik tüketimindeki \%1 artış ekonomik büyümeyi \%0.6 oranında artırmıştır.

Salahuddin ve Alam [14] çalışmalarında, 1985-2012 dönemi için OECD panel verilerini kullanarak Bilgi ve
İletişim Teknolojileri (BİT) kullanımı ve ekonomik büyümenin elektrik tüketimi üzerindeki kısa ve uzun vadeli etkilerini tahmin etmişlerdir. Çalışmada panel eşbütünleşme testi, Havuzlanmış Ortalama Grup Regresyon tekniği ve Dumitrescu-Hurlin nedensellik testi ve kesitsel bağımlılık varlığına göre panel birim kök testi kullanılmıștır. Elde edilen sonuçlar hem BIT kullanımı hem de ekonomik büyümenin hem kısa hem de uzun vadede elektrik tüketimini teşvik ettiğini göstermiştir. Nedensellik sonuçları ise elektrik tüketiminin ekonomik büyümeye neden olduğunu göstermiştir.

Bah ve Azam [15] çalışmalarında, 1971-2012 döneminde Güney Afrika için elektrik tüketimi, ekonomik büyüme, finansal gelişme ve $\mathrm{CO} 2$ emisyonları arasındaki nedensel ilişkiyi incelemişledir. Eşbütünleşme varlığını test etmek için Otoregressif Dağıtılmış Lag (ARDL) sınır testi kullanılırken, Toda ve Yamamoto artırılmış Granger nedensellik testini nedensellik yönünü belirlemek için kullanmışlardır. ARDL sınırları testi ile dahil edilen değişkenler arasında eşbütünleşme olduğunu, Toda ve Yamamoto Granger nedensellik testi ile de elektrik tüketimi ile ekonomik büyüme arasında bir nedensellik olmadığını göstermişlerdir.

Tunalı ve Ulubaş [1] çalışmalarında, 1970-2015 dönemi verileri kullanarak G7 ülkeleri için ekonomik büyüme ile elektrik enerji tüketimi arasındaki ilişkiyi analiz etmişlerdir. $\mathrm{Bu}$ amaç doğrultusunda, havuzlanmış en küçük kareler (Pooled OLS), olabilirlik oranı (LR), Breusch-Pagan LM, Score ve F testleri gerçekleştirmişlerdir. Uygun modeli belirlemek amaciyla Hausman spesifikasyon testi yapmışlar ve modelin sabit etkiler modeline uygun olduğunu belirlemişlerdir. Modelde ekonometrik varsayımlardan sapma olduğu tespit edilmiş ve varsayımdan sapmalara dirençli Driscoll- Kraay testi gerçekleştirilmiştir. Analiz sonucundan, elektrik enerjisi tüketimi, işgücü ve sermaye birikiminin anlamlı ve ekonomik büyümeyi pozitif etkilediği görülmüştür.

Öncel vd. [16] çalışmalarında, 1990-2011 dönemi için yıllık verilerle 22 OECD ülkesine ait elektrik tüketimi ile ekonomik büyüme arasındaki ilişkiyi incelemişlerdir. Zamanla değișen panel nedensellik analizi kullanarak, nedensellik ilişkisini 1991-2005 yılları için elektrik tüketiminden ekonomik büyümeye, 1995-2009 yılları için ise ekonomik büyümeden elektrik tüketimine doğru olduğunu göstermişlerdir.

Zhang vd. [17] çalışmalarında, Çin'deki elektrik tüketimi ve ekonomik büyüme arasındaki ilişkiyi incelemişlerdir. İlk olarak Çin'in elektrik tüketimi ve ekonomik gelişmesinin genel durumunu analiz etmişlerdir. Daha sonra Çin'in elektrik tüketimi ile ekonomik büyüme arasındaki ilişkiyi üç boyuttan, yani zaman, bölgesel ve endüstriyel boyuttan incelemişlerdir. 
Yenilmez ve Erdem [18] çalışmalarında, Türkiye ve $A B$ 'de tüketilen enerji türlerinin ekonomik büyüme üzerindeki etkisini Toda-Yamamoto nedensellik testi yardımıyla incelemişlerdir. Elde edilen sonuçlardan Türkiye için doğalgaz tüketiminden ekonomik büyümeye doğru, $\mathrm{AB}$ için ise petrol tüketiminden ekonomik büyümeye doğru tek yönlü nedensellik ilişkisinin varlığına ulaşılmıştır.

Yıldırım ve Dağdemir [19] çalışmalarında, Türkiye'de ekonomik büyüme ve elektrik tüketimi ilișkisini incelemişlerdir. Granger Nedensellik analizi ile nedensellik ilişkisinin tek yönlü olduğu görülmüştür. Elektrik Tüketimi, Gayri Safi Yurt İçi Hasıla'nın nedeni iken GSYIH, Elektrik Tüketimi'nin nedeni olmadığı sonucuna ulaşılmıştır.

Koç ve Saidmurodov [20] çalışmalarında, 1992-2014 yılları arası yıllık verilerini kullanarak Orta Asya (Kazakistan, Kırgızistan, Tacikistan, Türkmenistan ve Özbekistan) Cumhuriyetlerinin elektrik enerjisi, DYY ve ekonomik büyüme ilişkisini, panel veri kullanarak analiz etmişlerdir. Genel literatürden farklı olarak, üçüncü bir değişken olarak doğrudan yabancı yatırımı (DYY) da eklemişlerdir. Elde edilen bulgular doğrudan yabancı yatırımdan hem ekonomik büyümeye hem de elektrik enerji tüketimine doğru tek yönlü bir nedensellik ilişkisi mevcut olduğunu ancak ekonomik büyüme ile elektrik enerji tüketiminden doğrudan yabancı yatırıma doğru bir nedensellik olmadığını göstermiştir.

Borger ve Buongiorno [21] çalışmalarında, 19581981 yılları arasında Amerika Birleşik Devletleri'nin kağıt ve mukavva endüstrileri için yıllık toplam verimlilik artışı endeksleri hesaplamışlardır. Çalışma, her bir endüstrinin geri kalan girdilerin seviyesine bağlı olarak değişken maliyetleri asgariye indirdiği hipotezine dayanmaktadır.

Giroldo ve Hyman [22] çalışmalarında, kağıt ve kağıt ürünleri üretimi için enerji tüketim modeli sunmuşlardır. Modelin ABD Enerji Bakanlığı 1991 İmalat Enerji Tüketimi Anketi (MECS) verileriyle tutarlılığını ve diğer sektörlere uyumunu değerlendirmişlerdir.

Costanza ve Ruth [23] çalışmalarında, çeşitli sanayi verilerinin organizasyonunu kolaylaştırmak ve gelecekteki enerji kullanımını araştırmak için ABD'nin kağıt ve kağıt ürünü üretimi dinamik bilgisayar modelini sunmuşlardır.

Amil ve Buongiorno [24] çalışmalarında, maliyet minimizasyonu teorisi, talebin kağıt ve mukavvadan oluşan fiyatın negatif bir fonksiyonu olan kağıt ve mukavva için ulusal talep denklemlerini ve gayri safi milli hasılanın pozitif bir işlevini öneren modelin dinamik bir versiyonu, Avrupa Birliği ülkelerinden, gazete kağıdı, matbaa ve yazı kâğıdı ve diğer kağıt ve mukavvadan gelen verilerle tahmin etmişlerdir.
$\mathrm{Bu}$ çalışmanın amacı, kağıt ve kağıt ürünleri üretimi ve gayri safi yurt içi hasıla ile elektrik enerjisi tüketimi arasındaki ilişkiyi panel veri analizi ile modellemektir. Literatüre bakıldığında yapılan çoğu çalışmanın elektrik tüketimi ve ekonomik büyüme arasındaki ilişkiyi incelediği görülmektedir. Yapılan çalışmada ise kağıt ve kağıt ürünleri üretimi de dikkate alınarak elektrik tüketimi üzerindeki etkisi incelenmiştir. Bu nedenle çalışmanın literatüre katkı sağlanacağı düşünülmektedir. Bu doğrultuda, 20062015 yılları arasında 20 OECD ülkesi için panel veri seti oluşturulmuştur. Model için yatay kesit bağımlılığı, değişen varyans ve otokorelasyon varsayımları sınanmış ve varsayımlardan sapma olduğu görülmüştür. Bu saplamara dirençli DriscollKraay tahmin edicisi kullanılarak parametreler tahmin edilmiştir. $\mathrm{Bu}$ çalışmanın önceki çalışmalardan farkı, kağıt ve kağıt ürünleri üretimi değişkeninin de modele dahil edilerek elektrik enerjisi tüketimine etkisinin incelenmesi, analizin yapıldığı ülke grubu ve yıl aralığının güncelliğidir.

\section{Materyal ve Metot}

Çalışmada, ülkelerin refah düzeyini belirlediği düşünülen GSYH ve kağıt ve kağıt ürünleri üretimi (KKU) değişkenlerinin, elektrik tüketimi (ET) üzerindeki etkisi panel veri analizi ile incelenmiştir. $\mathrm{Bu}$ amaç doğrultusunda, 34 OECD ülkesinden kağıt ve kağıt üretimi gerçekleştiren ve yıl bazında birkaç yılık üretimi eksik olan 20 OECD ülkesi ele alınmıştır. Böylece çalışmaya dahil edilen ülkeler Türkiye, Estonya, Almanya, İspanya, İrlanda, Fransa, Macaristan, İtalya, Avusturya, Hollanda, Portekiz, Polonya, Slovakya, Slovenya, İsveç, Finlandiya, Norveç, Birleşik Krallık ve Danimarka olarak belirlenmiştir. Bu ülkelere ait 2006-2016 yıllarını kapsayan elektrik tüketimi (ET), kağıt ve kağıt ürünleri üretimi (KKU) değişkenlerine ait veriler EUROSTAT veri tabanından, gayri safi yurt içi hasıla verileri ise Wordbank veri tabanından elde edilmiştir. Danimarka'nın 2012, İrlanda'nın 2011, Fransa'nın 2012, İtalya'nın 2012, 2013, ve 2016, Macaristan'ın 2015, Slovenya'nın 2012, İsveç'in 2012, ve son olarak Türkiye'nin 2015 ve 2016 yıllarına ait kağıt ve kağıt üretimi değerleri eksiktir. Ülkelere ait eksik veriler Stata programında ipolate komutuyla kayıp değer olarak tanıtılmıștır. Değişkenlerin doğal logaritmaları alınarak ampirik analizler uygulanmıștır.

Panel veri; ülkeler, bölgeler, şehirler, firmalar ve bireyler gibi yatay kesit birimlere ait verilerin belirli bir dönem içerisinde gözlemlenmesi ya da bir araya getirilmesi sonucu elde edilmektedir. Ekonomik ilişkilerin panel veri kullanılarak oluşturulan regresyon modelleri yardımiyla tahmin edilmesi yöntemine ise "panel veri analizi" denilmektedir [25]. $\mathrm{Bu}$ analizde, zaman serileri ile kesit serileri bir araya getirilerek hem zaman hem de kesit boyutuna sahip veri seti olușturulmaktadır. İki boyutun bir arada kullanılması daha fazla bilgi kullanımı ve serbestlik derecesinde artış sağlamaktadır. Gözlem sayısındaki 
artış, ölçülen iliş̧kiye daha fazla değişkenlik katarak, çoklu doğrusal bağıntı problemini ortadan kaldırmaktadır [26].

Model parametrelerinin tahmininde kullanılacak uygun tahmin yönteminin belirlenebilmesi için ilk olarak, değişkenlerin yatay kesit bağımlılığının olup olmadığı Pesaran, Friedman ve Frees testleri yardımıyla incelenmiștir. Pesaran [27] test istatistiği $N>T$ durumunda kullanılmaktadır. Bu test yatay kesit kalıntıları arasındaki korelasyon katsayılarının toplamına dayandırılmaktadır. Test istatistiği $\mathrm{d}=\mathrm{N}(\mathrm{N}$ 1)/2 serbestlik derecesi ile ki-kare dağlımına sahiptir. Friedman [28] R testi Spearman'nın rank korelasyon katsayısına dayalı parametrik olmayan bir testtir. Test istatistiği (T-1) serbestlik derecesi ile asimtotik ki-kare dağılımına sahiptir. Panel boyutu için $T<N$ olması durumunda kullanılır. Frees $Q$ testi ise Friedman test istatistiğinin hesaplanmasında kullanılan sıra korelasyon değerinin kareleri toplamına dayalı bir testtir [29]. Daha sonra, Pesaran [30] tarafından geliştirilen CADF (Cross-Sectionally Augmented Dickey Fuller) birim kök testi yardımıyla değişkenlerin durağanlık seviyeleri belirlenmiştir. Pesaran [30] CADF testi, bireysel serilerin birinci farkları ve gecikme düzeylerinin yatay kesit ortalamaları ile ADF regresyonunun genișletilmiș şeklidir. Son olarak, değişen varyans ve otokorelasyon varsayımlarının sağlanıp sağlanmadığına bakılarak varsayımlardan sapmalara dirençli Diriskol Kraay tahmincileri ile parametreler tahmin edilmiştir.

Panel veri analizlerinde kullanılan modelde yatay kesit bağımlılı̆̆ı, değișen varyans ve otokorelasyon problemleri olması durumunda Driscoll-Kraay Tahmin edicisi kullanılmaktadır. Ayrıca, $\mathrm{T}>\mathrm{N}$ durumunda bile Driscoll-Kraay Tahmincisi, değişen varyans varlığında tutarlı, uzamsal ve dönemsel korelasyonun genel formlarında dirençli standart hatalar üretmektedir. Ayrıca dengesiz panel veri modellerinde de kullanılabilmektedir [25].

\section{Bulgular}

Seriler arasında yatay kesit bağımlılı̆̆ının (YKB) varlığı göz önünde bulundurulmadan analiz yapılması elde edilecek sonuçları önemli ölçüde etkilemektedir [31]. Ayrıca birim kök testleri seçilirken YKB'nin dikkate alınmaması, elde edilen analiz sonuçlarını sapmalı ve tutarsız hale getirecektir. Yatay kesit bağımlılığı panel veri modelinin her bir ülke/bölge vb. birimler için hesaplanan hata terimleri arasinda korelasyonun varlığını ifade etmektedir [25]. Başka bir ifadeyle yatay kesit bağımlılığı ülkelerin birbirlerine bağımlı olması veya ülkelerden birine gelen bir şokun diğer ülkeleri etkilemesidir. $\mathrm{Bu}$ nedenle analize başlamadan önce, YKB'nın varlığının test edilmesi gerekmektedir. Birimler arası korelasyon testleri sonuçları Tablo1'de verilmiştir.
Tablo 1. Birimler arası korelasyon testleri ve sonucları

\begin{tabular}{|c|c|c|}
\hline Test & Test İstatistiği & p-değeri \\
\hline Pesaran & 15.234 & 0.0000 \\
\hline Friedman & 101.758 & $\begin{array}{l}0.0000 \\
\text { Q dă̆ılımı için kritik } \\
\text { değer }\end{array}$ \\
\hline Frees & 9.603 & $\begin{array}{l}0.10 \text { için } 0.4892 \\
0.05 \text { için } 0.6860 \\
0.01 \text { için } 1.1046\end{array}$ \\
\hline
\end{tabular}

Tablo 1'de görüldüğü gibi, kullanılan üç test içinde "birimler arasında korelasyon yoktur" şeklindeki yokluk hipotezi reddedilerek modelde birimler arası korelasyon olduğu sonucuna varılmıştır. Değişkenlerde yatay kesit bağımlılı̆̆ olması durumunda yapılacak olan durağanlık sınamalarında ikinci nesil panel birim kök testlerinin kullanılması gerekmektedir. Bu çalışmada, değişkenlerde yatay kesit bağımlılığı (Tablo 1) olmasından dolayı Pesaran [30] tarafından geliştirilen CADF ikinci nesil birim kök testi kullanılmış ve sonuçları Tablo 2'de verilmiştir.

Tablo 2. CADF testi sonuçları

\begin{tabular}{ccccc}
\hline Değişkenler & \multicolumn{2}{c}{ Düzey seviyesi } & \multicolumn{2}{c}{ Birinci Fark } \\
Z[t-bar] & $\begin{array}{c}\text { p- } \\
\text { değeri }\end{array}$ & Z[t-bar] & $\begin{array}{c}\text { p- } \\
\text { değeri }\end{array}$ \\
\hline ET & 2.205 & 0.986 & -3.277 & 0.001 \\
KKU & -1.420 & 0.078 & -2.979 & 0.001 \\
GSYH & 0.216 & 0.585 & -5.880 & 0.000 \\
\hline
\end{tabular}

Tablo 2 incelendiğinde düzey seviyede $\mathrm{I}(0)$, üç seri için de "birim kök içermektedir" şeklindeki yokluk hipotezi reddedilememektedir ( $p>0.05)$. Bu da düzey seviyede durağan olmadıklarını göstermektedir. Seriler seviyelerinde durağan değilse, ilgili serilerin farkları alınarak durağan hale getirilir. Bu nedenle serilerin birinci farkları alınıp I(1) CADF birim kök testi tekrar gerçekleştirilmiş ve üç değiş̧kenin seviyelerinde I( 0$)$ durağan olmadıkları ancak birinci dereceden farkları I(1) alındığında durağan hale geldikleri görülmüştür $(\mathrm{p}<0.05)$. Çalışmada ele alınan modelde ekonometrik varsayımlar olan otokorelasyon (Durbin-Watson: 0.561, Baltagi-Wu LBI: 0.894) ve değişen varyans (ki-kare: 545.53, p: 0.000 ) sorunları tespit edilmiştir. Tahmin edilen modelde, varsayımlardan sapmalar olduğu görülmüştür. Bu durum, hata terimlerinin varyanskovaryans matrisini birim matris olmaktan çıkarmaktadır. $\mathrm{Bu}$ nedenle, hata terimine ilişkin yapılan varsayımlardan sapmalara dirençli tahminler veren Driscoll-Kraay tahmincisi kullanılmıștır. Driscoll-Kraay tahmin yöntemiyle elde edilen sonuçlar Tablo 3'te verilmiştir.

Tablo 3. Driscoll-Kraay tahmin sonuçları

\begin{tabular}{ccccc}
\hline \multicolumn{5}{c}{ Driscoll-Kraay regresyon modeli } \\
& Katsayı & Standart Hata & t değeri & p değeri \\
\hline KKU & 0.224 & 0.037 & 6.03 & 0.000 \\
GSYH & 0.616 & 0.026 & 22.97 & 0.000 \\
Cons & 0.661 & 0.099 & 6.66 & 0.000 \\
$\mathrm{~F}(2,10)$ & 8402,49 & & & 0.000 \\
$\mathrm{R}^{2}$ & 0.919 & & & \\
\hline
\end{tabular}


Tablo 3'te yer alan tahmin sonuçları incelendiğinde 20 OECD ülkesinin 2006-2016 dönemleri arasındaki veriler kullanılarak oluşturulan modelde yer alan, kağıt ve kağıt ürünleri üretimi, gayri safi yurt içi hasila ve model sabitine ait parametrelerin \%95 güven düzeyinde istatistiksel olarak anlamlı olduğu görülmektedir. Bununla birlikte, modelin kağıt ve kağıt ürünleri üretimi ve gayri safi yurt içi hasıla değişkenleri, elektrik tüketimi değişkenini yaklaşık olarak \%92 oranında açıklamaktadır. Kağıt ve kağıt ürünleri üretimindeki $\% 1$ 'lik bir artış elektrik tüketiminde $\% 0.22$, gayri safi yurt içi hasıladaki $\% 1$ 'lik bir artış ise elektrik tüketiminde yaklaşık olarak \%0.62'lik bir artışa neden olmaktadır.

\section{Tartışma ve Sonuç}

Son yllarda, küreselleşmeyle birlikte elektrik enerjisi tüketimi ekonomik kalkınmanın en önemli girdilerinden biri haline gelmiştir. Günlük yaşamda çok yoğun bir şekilde kullanılan ve üretim ve tüketim gibi ekonomik faaliyetlerle yakın ilişkisi olan elektrik enerjisi ülkelerin ekonomik ve sosyal gelişmelerinin sağlamasında, ekonomik büyüme ve yaşam standartlarının yükseltilmesinde önemli bir role sahiptir. Ülkelerin elektrik kullanımı nüfus, sosyal ve ekonomik gelişme düzeyi, sanayileşme ve kentleşme seviyesi, teknolojik gelişmişlik gibi pek çok sosyoekonomik faktöre bağlı olarak şekillenmektedir. Üretim sürecine katılmakta ve ülkelerin milli hasılaları arttıkça, ekonomik hayatın vazgeçilmez bir parçası olan elektrik enerjisi tüketimleri artmaktadır. Bununla birlikte kağıt sektörü de ekonomik büyümeye son derece duyarlıdır. Dünyada kağıt üretimi ve tüketimi gelişen teknoloji ve kağıdın kullanım alanının genişlemesi ile her geçen gün artmaktadır. $\mathrm{Bu}$ çalışmada 2006-2016 dönemine ait 20 OECD ülkesi için kağıt ve kağıt ürünleri üretimi ve gayri safi yurt içi hasıla ile elektrik enerjisi tüketimi arasındaki ilişki incelenmiştir. Analiz için modele bağımlı değişken olarak, elektrik enerjisi tüketimi, bağımsız değişken olarak, kağıt ve kağıt ürünleri üretimi ve gayri safi yurt içi hasıla değişkenleri alınmıştır. Panel veri analizlerinde uygun tahmin yöntemini belirlemek için ekonometrik varsayım testleri olan yatay kesit bağımllı̆̆ğ değișen varyans ve otokorelasyon testleri yapılmıştır. Elde edilen test sonuçlarına göre üç varsayımdan da sapmanın olduğu görülmüştür. Modele bu varsayımların üçünden de sapmaya dirençi olan Driscoll-Kraay tahmin edicisi uygulanmıştır. Analiz sonucuna göre kağıt ve kağıt ürünleri üretiminde meydana gelecek \%1'lik bir artış elektrik enerjisi tüketimini $\% 0.22$ oranında, kişi başı gayri safi yurt içi hasıladaki yüzde 1 'lik bir artış elektrik tüketiminde yaklaşık olarak \%0.62 dolayında arttırdığı bulgusuna ulaşılmıştır. Çalışmada elde edilen sonuçlar, ulusal ve uluslararası literatürdeki diğer çalışmalarla karşılaştırıldığında, elektrik enerjisi tüketimi ve ekonomik büyüme arasında ilişki bulunması açısından paralellik göstermektedir. Elektrik tüketimi ve ekonomik büyüme arasında güçlü bir ilişki olması enerjinin ekonomiye bağımlı olduğunu göstermektedir.
Üretimin her sektöründe elektrik tüketimini arttıran ekonomik büyüme, toplumun yaşam standartlarının yükselmesini sağlamakta ve bireylerin hayatlarında da elektrik tüketimini vazgeçilmez kılmaktadır. Ülkelerin sanayileşme süreçlerinin tamamlanmasında da elektrik enerjisinin yeri tartışılmazdır.

Çalıșmada ele alınan ülke grubunun elektrik enerjisine bağımlı oldukları gözönünde bulundurulursa, bu ülkelerin ekonomi ve enerji politikalarında bazı değişiklikler yapmaları gerekmektedir. Ayrıca konut ve sanayi sektöründe enerji tasarrufuna gidilmesi ile enerjiyi daha az kullanan ve ekonomik büyümeyi aynı ölçüde etkileyen sektörlerin teşvik edilmesi gerekmektedir.

Ek olarak, bu çalışmada kağıt ve kağıt ürünleri üretiminin de elektrik enerjisi tüketimine etkisinin de incelenmesi ile literatüre mütevazi bir katkı sağlamaktadır. Yoğun enerji kullanan kağıt sektörünün elektrik enerjisinden kaynaklanan maliyetin azaltılması doğrultusunda belli indirimlerin sağlanması gerekmektedir. Enerji ödemelerinde en büyük paya sahip olan elektrik enerjisinin tasarrufu için önlemler alınmalıdır. Ayrıca 1 ton atık kağıt dönüşümü ile 4.100 kwh elektrik enerjisi tasarrufu sağlanabildiği dikkate alınarak atık kağıtların geri dönüşüme kazandırılmalıdır.

\section{Kaynakça}

[1] Tunalı, H., Ulubaş, M.A. 2017. Elektrik Enerjisi Tüketimi ve Ekonomik Büyüme Arasındaki İlişki: G7 Ülkeleri Üzerine Bir Uygulama (1970-2015). Selçuk Üniversitesi Sosyal Bilimler Meslek Yüksekokulu Dergisi, 20 (1), 1-13.

[2] Ersoy, A.Y. 2010. Ekonomik Büyüme Bağlamında Enerji Tüketimi. Akademik Bakış Dergisi, 20(1), 1-11.

[3] Kapusuzoglu, A., Karan, M. B. 2010. Gelişmekte Olan Ülkelerde Elektrik Tüketimi ile Gayri Safi Yurt İçi Hasıla (GSYiH) Arasındaki EşBütünleşme ve Nedensellik İlişskisinin Analizi: Türkiye Üzerine Ampirik Bir Çalışma. Business \&Economics Research Journal, 1(3), 57-68.

[4] İsmiç, B. 2015. Gelişmekte Olan Ülkelerde Elektrik Tüketimi. Ekonomik Büyüme ve Nüfus İlişkisi. Çankırı Karatekin Üniversitesi İktisadi ve İdari Bilimler Fakültesi Dergisi, 5(1), 1-16.

[5] Şirin, Y. N., Denizli, A. E. 2009. Elektrik Sektöründe Özelleştirmeye Genel Bir Bakış ve Öneriler. Ege Bölgesi Enerji Forumu 12-13 Ekim 2009.

[6] Atik, C., Ok, K. 2017. Türkiye'de Kâğıt Üretimi ve Sürdürülebilir Kalkınma. doi: 10.13140/rg.2.2.32294.93761

[7] Çevik, B. 2016. Kağıt ve Kağıt Ürünleri Sektörü, Türkiye İş Bankası İktisadi Araştırmalar Bölümü Raporu, 33. 
[8] Ghaderi, S.F., Azadeh, A., Mohammadzadeh, S. 2006. Modeling and Forecasting Electricity Demand for Majoreconomic ectors in Iran. Information Technology Journal, 5(2), 260-266.

[9] Saatçi, M., Dumrul, Y. 2013. Elektrik tüketimi ve ekonomik büyüme ilișkisinin dinamik bir analizi: Türkiye örneği. Uludağ Üniversitesi İktisadi ve İdari Bilimler Fakültesi Dergisi, 32(2), 1-24.

[10] Altıntaş, H., Mercan, M. 2015. Elektrik Tüketimi ve Ekonomik Büyüme İlişkisi: G-11 Ülkeleri Örneğinde Panel Eşbütünleşme ve Nedensellik Uygulaması. TISK Academy/TISK Akademi, 10(20), 319-347.

[11] Ergün, S., Polat, M. A. 2015. OECD ülkelerinde CO2 emisyonu, elektrik tüketimi ve büyüme ilişkisi. Erciyes Üniversitesi Iktisadi ve Idari Bilimler Faküeltesi Dergisi, (45), 115.

[12] Karanfil, F., Li, Y. 2015. Electricity consumption and economic growth: exploring panel-specific differences. Energy Policy, 82, 264-277.

[13] Eren, M. V., Polat, M. A., Aydın, H. İ. 2016. Türkiye'de yapısal kırılmalı testlerle elektrik tüketimi ve ekonomik büyüme arasındaki ilişkinin analizi. Akademik Bakıș Uluslararası Hakemli Sosyal Bilimler Dergisi, (56), 275-289.

[14] Salahuddin, M., Alam, K. 2016. Information and Communication Technology, electricity consumption and economic growth in OECD countries: A panel data analysis. International Journal of Electrical Power \& Energy Systems, 76, 185-193.

[15] Bah, M.M., Azam, M. 2017. Investigating the relationship between electricity consumption and economic growth: Evidence from South Africa. Renewable and Sustainable Energy Reviews, 80, 531-537.

[16] Öncel, A., Kırca, M., İnal, V. 2017. Elektrik Tüketimi ve Ekonomik Büyüme İlişkisi: OECD Ülkelerine Yönelik Zamanla Değișen Panel Nedensellik Analizi. Maliye Dergisi, 173(1), 398420.

[17] Yenilmez, F., Erdem, M.S. 2018. Türkiye ve Avrupa Birliği'nde Ekonomik Büyüme ile Enerji Tüketimi Arasındaki İlişki: Toda-Yamamoto Nedensellik Testi. Eskişehir Osmangazi Üniversitesi Sosyal Bilimler Dergisi, 19(1), 71-95.
[18] Yıldırım, C., Dağdemir, Ö. 2018. Türkiye'de ekonomik büyüme ve elektrik tüketimi ilişkisi. Sakarya İktisat Dergisi, 7(4), 57-76.

[19] Zhang, C., Zhou, K., Yang, S., Shao, Z. 2017. On electricity consumption and economic growth in China. Renewable and Sustainable Energy Reviews, 76, 353-368.

[20] Koç, S., Saidmurodov, S. 2018. Orta Asya Ülkelerinde Elektrik Enerjisi, Doğrudan Yabancı Yatırımı ve Ekonomik Büyüme İlişkisi. Ege Academic Review, 18(2).

[21] Borger, B.D., Buongiorno J. 1985. Productivity Growth in The Paper and Paperboard Industries: a Variable Cost Function Approach. Canadian Journal of Forest Research, 15(6), 1013-1020.

[22] Giraldo, L., Hyman, B. 1996. An Energy Processstep Model for Manufacturing Paper and Paperboard. Energy, 21(7-8), 667-681.

[23] Costanza, R., Ruth, M. 1998. Using Dynamic Modeling to Scope Environmental Problems and Build Consensus. Environmental management, 22(2), 183-195.

[24] Chas-Amil, M.L., Buongiorno, J. 2000. The demand for Paper and Paperboard: Econometric Models for the European Union. Applied Economics, 32(8), 987-999.

[25] Tatoğlu, F.Y. 2012. Panel veri ekonometrisi. Beta Yayınevi, İstanbul-Türkiye, 334s.

[26] Hsiao, C. (2014). Analysis of panel data (No. 54). Cambridge university press.

[27] Pesaran, M. H. 2004. General diagnostic tests for cross section dependence in panels.

[28] Friedman, M. 1937. The use of ranks to avoid the assumption of normality implicit in the analysis of variance. Journal of the american statistical association, 32(200), 675-701.

[29] Güriș, S. 2015. Stata ile panel veri modelleri. Der yayınevi.

[30] Pesaran, M.H. 2007. A Simple Panel Unit Root Test in The Presence of Cross-section Dependence. Journal of Applied Econometrics, 22(2), 265-312.

[31] Breusch, T.S., Pagan, A.R. 1980. The Lagrange Multiplier Test and its Applications to Model Specification in Econometrics. The Review of Economic Studies, 47(1), 239-253. 